\title{
Voice in Istanbul Greek: A Language Contact Explanation
}

\author{
Umut Gülsün*
}

\begin{abstract}
The aim of this research is analyzing Voice-related constructions in Istanbul Greek - anticausatives in particular - and addressing the synchronic differences between the Istanbul dialect and Standard Greek in terms of these constructions from a language-contact perspective. As a morphosyntactic analysis of Istanbul Greek, this research is the first of its kind, and is based on data collected from native speakers, namely the Istanbul Greeks. Voice-related constructions in Greek involve regular use of non-active morphology. Hence, the empirical domain of this research covers the use of non-active morphology in Istanbul Greek. My hypothesis is that the markedness of Istanbul Greek anticausatives is correlated with the markedness of their Turkish counterparts, contrary to Standard Greek. By markedness, I refer to the existence of an overt exponent for the binary morphological distinction between active and non-active forms. I claim that language contact between Istanbul Greek and Turkish is a possible reason for the dialectal differences between Istanbul Greek and Standard Greek in terms of the marking of Voice-related constructions.

In terms of setting the theoretical background for Voice-related constructions in Standard Greek, I utilized Alexiadou et al.'s (2015) work about Standard Greek marked/unmarked anticausatives. I also collected data on Standard Greek from ten speakers, which diverged from Alexiadou et al.'s (2015) explanation of Voicerelated constructions in the standard dialect. For setting the linguistic background on Istanbul Greek, I utilized the study of Pandelidis (2019). To offer a morphosyntactic explanation for the dialectal differences observed in the Istanbul Greek data, I utilized language contact concepts such as interference (Thomason 2003), convergence (Clyne 2003), valency-copying (Grossman and Witzlack-Makarevich 2019), morphophonological explanations such as the presence vs. absence of an augment, and Haspelmath's (1993) spontaneity scale, among others.
\end{abstract}

Keywords. Istanbul Greek; Turkish; language contact; Voice; anticausatives; morphosyntax; non-active morphology; markedness; Greek

1. Introduction. This article focuses on anticausatives in Istanbul Greek and addresses the synchronic differences between the Istanbul dialect and Standard Greek regarding such Voicerelated constructions from a language-contact perspective. ${ }^{1}$ Hence, the data for this research was collected from native speakers of Istanbul Greek. As Voice-related constructions in Greek involve non-active marking, this research focuses on the usage of non-active morphology in Istanbul Greek. The claim of this article will be that the markedness of Istanbul Greek anticausatives is correlated with the markedness of their Turkish counterparts, contrary to Standard Greek. What is meant by markedness is the existence of an overt exponent for the binary morphological distinction between active and non-active forms. A possible reason for the

\footnotetext{
* Special thanks to Metin Bağrıaçık. Author: Umut Gülsün, Boğaziçi University (umut.gulsun@boun.edu.tr)

${ }^{1}$ I assume that the Standard Greek anticausative forms represent the inherited distribution of Greek anticausative morphology. The necessary diachronic analysis to support this assumption is beyond the scope of this article.
} 
dialectal differences between Istanbul Greek and Standard Greek in terms of the marking of Voice-related constructions, I claim, is language contact between Istanbul Greek and Turkish.

The article is structured as follows: section 2 offers are brief sociolinguistic background on Istanbul Greek, section 3 sets the theoretical background on Voice-related constructions in Standard Greek utilizing Alexiadou et al.'s (2015) work about Standard Greek marked/unmarked anticausatives, section 4 offers a brief background on Turkish non-active morphology, section 5 puts forth the methodology of this research, sections 6-7-8 present Istanbul Greek data and the relevant discussion, and section 9 concludes the article.

2. Sociolinguistic background. The Greek community of Istanbul (aka Constantinopolites or commonly referred to as "Rums") is an indigenous ethnoreligious group that has long existed, withstanding pressure and heavy emigration to Greece. Although the Orthodox Greek population in Turkey is now confined to Istanbul (Poli), İzmir (Smyrna), Bozcaada (Tenedos), and Gökçeada (Imbros) - along with the scattered crypto-Christians here and there - the Greek language was spoken throughout Asia Minor before World War I and the population exchange between Greece and Turkey in 1924. The dialects spoken in Asia Minor at the beginning of the $20^{\text {th }}$ century included Cappadocian, Pontic, Silliot, Mani, Gyolde among many (a small population of Muslim Pontic speakers remain in Trabzon, together with a small population of Greek speakers in Cunda, Ayvalik ${ }^{2}$ ). As the population exchange targeted Asia Minor, but not Istanbul, more than 100,000 Greeks could remain in the city (Komondouros \& McEnteeAtalianis 2007). However, the Greek population in Istanbul has been decreasing gradually since then. Among the reasons for the heavy emigration of Greeks out of the city are the labour battalions that recruited non-Muslims during World War II (Yirmi Kur'a Askerlik), the Capital Tax in 1942 that targeted non-Muslims (Varlık Vergisi), the Istanbul Pogrom of September 1955 against the non-Muslims of the city (6-7 Eylül), the 1964 deportation of Istanbul Greeks who held Greek passports (64 Sürgünü), and the Cyprus-related pressures against Istanbul Greeks. Today, the Greek population in Istanbul is estimated to be around 2500 people (Rompopoulou 2018). The Greek population is mainly located in Pera, Tatavla, Yeşilköy (Agios Stefanos), Bakırköy (Makrihori), Kadıköy (Chalkidona), the neighborhoods along the Bosphorus like Yeniköy (Nihori), and the islands of Istanbul (Prinkiponisia).

3. Anticausatives in Standard Greek. Let us first start with defining anticausative verbs. Anticausatives are unaccusative verbs (intransitive verbs whose syntactic external arguments are not semantic agents) that can alternate as in (1):

(1) a. The soup burnt.

b. Eleni burnt the soup.

In this example, (1a) is the anticausative counterpart of (1b) whereas (1b) is the causative counterpart of (1a). For unaccusatives that can alternate like (1), the sole argument of the intransitive variant and the object of the transitive variant bear the same thematic relationship to the verb. However, there are also unaccusative verbs that do not alternate as in (1). Such verbs are called pure unaccusatives. An example for a pure unaccusative is given in (2):

\footnotetext{
2 The Greek speakers in Cunda are second generation Cretan immigrants whose ancestors were relocated to Cunda during the population exchange between Greece and Turkey (Kaya 2011). Today the speakers there are from Crete, but before the population exchange (in 1910) they were either locals or from the island of Mytilene.
} 

a. The
vase
fell.
b. * Eleni fell the vase.

However, the reader should notice that from a typological perspective, the alternation can be lexical as in $(2 \mathrm{c})$ :

$$
\text { c. Eleni } \begin{aligned}
& \text { dropped the vase. } \\
& \text { fall+CAUSE }
\end{aligned}
$$

In this research, I will try to examine unaccusatives in Istanbul Greek that are of type (1), namely anticausatives. Unlike English, in Greek, the members of the causative-anticausative alternation may have special morphology on them. In such cases, the causative counterpart carries active morphology as in (3a), and the anticausative counterpart carries non-active morphology as in (3b):

$$
\begin{aligned}
& \text { a. O Yannis ekapse ti supa. } \\
& \text { the Yannis.NOM burnt.ACT the soup. } \\
& \text { "Yannis burnt the soup." } \\
& \text { b. I supa } \\
& \text { the soup.NOM buike. } \\
& \text { "The soup burnt." }
\end{aligned}
$$$$
\text { the Yannis.NOM burnt.ACT the soup.ACC }
$$

(Alexiadou et al. 2015)

As seen in example (3), the transitive and the anticausative forms in Greek may differ in terms of active morphology vs. non-active morphology. Apart from the causative-anticausative alternation, the non-active form is also used in a number of further environments in Greek. One of these is passive structures. An example for the passive is given in (4):

$$
\begin{array}{llll}
\text { (4) To vivlio } & \text { diavastike } & \text { htes. } \\
\text { the book.NOM read.NACT } & \text { yesterday } \\
\text { "The book was read yesterday." } &
\end{array}
$$

(Alexiadou et al. 2015)

In Standard Greek, anticausatives come in three types, or classes. One class is the anticausatives that are formed with non-active morphology. Let us call this Class A (Alexiadou, Anagnostopoulou \& Schäfer 2015). The verb keo 'burn', which we have seen before in (3), belongs to Class A. Another type of anticausative in Standard Greek, which we will call Class B, carries active morphology in the intransitive context as well (Alexiadou et al. 2015):

$$
\begin{aligned}
& \text { a. O Yannis adiase ti sakula. } \\
& \text { the Yannis.NOM emptied.ACT the bag.ACC } \\
& \text { "Yannis emptied the bag." } \\
& \text { b. I sakula adiase. } \\
& \text { the bag.NOM emptied.ACT } \\
& \text { "The bag emptied." }
\end{aligned}
$$

(Alexiadou et al. 2015)

Finally, verbs that are of the third type of anticausatives in Standard Greek can bear both active and non-active morphology, which means that they are optionally marked (Alexiadou \& Anagnostopoulou 2004). We will categorize these verbs in Class C (Alexiadou et al. 2015): 


a. O sismos gremise to ktirio.
the earthquake.NOM demolished the building.ACC
"The earthquake demolished the building."
b. To ktirio gremise apo mono tu.
the building collapsed.ACT by itself
"The building collapsed by itself."
c. To ktirio gremistike
the building collapsed.NACT apo mono tu.
"The building collapsed by itself."

(Alexiadou et al. 2015)

Similar to Standard Greek, we could classify anticausatives in Istanbul Greek in the same manner: Class A (non-active marking), Class B (unmarked), and Class C (optional marking). However, as I will show in this paper, many verbs in Istanbul Greek behave different than their Standard Greek counterparts in terms of marking and hence their class membership; for example, the Standard Greek Class A verb vithizo (sink) and the Standard Greek Class B verb anigo (open) are both Class $\mathrm{C}$ verbs in Istanbul Greek. Similarly, the Standard Greek Class C verb zesteno (heat/warm up, as in "the house warmed up") is a Class A verb in Istanbul Greek. Hence, the major aim of this study is to pin down and explain the dialectal differences between Istanbul Greek and Standard Greek in terms of the marking of anticausatives verbs (and passives). In an attempt to account for these discrepancies, I invoke an analysis in which, I claim, Turkish influence has a decisive role.

4. Non-active morphology in Turkish. As we will see in the following sections, Turkish influence on Istanbul Greek (IG) verbal morphology, I claim, is related to the morphological marking of the Turkish counterparts of the IG verbs in question. Hence, I want to give an overview of the relevant non-active markers for Turkish verbs.

$-(I)$ ş: In many grammars of Turkish, this suffix is considered as a reciprocal suffix, along with denoting some other special meanings, such as an unorganized manner, a shared act, intensity, or collectivity (Göksel and Kerslake 2005; Underhill 1985; van Schaaik 2020). Moreover, according to Göksel and Kerslake (2005), almost all verbs ending in the suffix -(I)ş are intransitive. Then, I claim that the suffix $-(I)$ ş may be considered as a non-active marker in Turkish.

$-(I) n$ and $-(I) l$ : These morphemes are used in passives and reflexives, together with middle and marked anticausatives in Turkish (Göksel 1993; Gündoğdu 2016). Hence, -(I)n and $-(I) l$ are non-active verbal markers in Turkish. I use red marking for Turkish non-active suffixes throughout the text in order to ease reading.

5. Methodology. For this study, I collected grammaticality judgments from speakers of both Standard Greek and Istanbul Greek. The stimuli involved a set of Greek sentences built over 25 verbs common to Standard and Istanbul Greek ${ }^{3}$. A pair of sentences was formed on each verb; one with non-active morphology (marked) and one with active (unmarked). The informants were asked to judge the grammaticality of these options (none and either one are also licit answers: either one means that both options are grammatical, none means that none of the options are

\footnotetext{
${ }^{3}$ The data in this study has been collected as part of the project "Türkiye'de Dil Etkileşimi: Belgeleme ve Çözümleme" [Language Contact in Turkey: Documentation and Analysis (3.8.2016-2.8.2018) Boğaziçi University Research Fund \#11500].
} 
grammatical). The Turkish translations of these verbs were taken from one of the Istanbul Greek informants.

The informants that participated in the study are speakers of Istanbul Greek (IG) and Standard Greek (SG). I interviewed nine IG speakers and ten SG speakers. Most of the interviews with the informants were carried out via Zoom. It should be noted here that it is hard to reach Istanbul Greek informants due to the small size of the community, and the sociopolitical factors that arise from the previous pressures on Istanbul Greeks. As the sample size is small for both dialects, the findings in this study can only be interpreted as tendencies rather than facts.

In terms of demographics, Istanbul Greek informants that participated in this study are all generations-long Istanbulites who are Greek-Turkish bilinguals. Among the Standard Greek speakers, I should note that two have Cretan ancestry, and may have also been influenced by the Cretan dialect apart from the Standard dialect. In the next section, we will start to examine the Istanbul Greek data.

6. Class A anticausatives in Istanbul Greek. Table 1 shows Class A verbs in Istanbul Greek.

\begin{tabular}{|c|c|c|c|c|c|c|c|c|}
\hline Verb & $\begin{array}{l}\text { Non- } \\
\text { active } \\
(\%)\end{array}$ & $\begin{array}{c}\text { Active } \\
\text { (\%) }\end{array}$ & $\begin{array}{l}\text { Either } \\
\text { one } \\
(\%)\end{array}$ & $\begin{array}{l}\text { Non- } \\
\text { active } \\
(\%)\end{array}$ & $\begin{array}{c}\text { Active } \\
\text { (\%) }\end{array}$ & $\begin{array}{l}\text { Either } \\
\text { one } \\
(\%)\end{array}$ & Marking & Class \\
\hline Non-act $\% \geq 85$ & \multicolumn{3}{|c|}{ Istanbul Greek } & \multicolumn{3}{|c|}{ Standard Greek } & Turkish & St. Gr. \\
\hline mazevo (toplandi) & 100.0 & 0.0 & 0.0 & 90.0 & 10.0 & 0.0 & Non-act & A \\
\hline egatalipo (terk edildi) & 100.0 & 0.0 & 0.0 & 100.0 & 0.0 & 0.0 & Non-act & A \\
\hline psino (pişti) & 100.0 & 0.0 & 0.0 & 100.0 & 0.0 & 0.0 & 0 & A \\
\hline hino (döküldü) & 100.0 & 0.0 & 0.0 & 100.0 & 0.0 & 0.0 & Non-act & A \\
\hline prizo (şişti) & 100.0 & 0.0 & 0.0 & 88.9 & 11.1 & 0.0 & 0 & A \\
\hline skizo (y1rtıld1) & 88.9 & 0.0 & 11.1 & 90.0 & 0.0 & 10.0 & Non-act & A \\
\hline kovo (koptu) & 88.9 & 0.0 & 11.1 & 80.0 & 20.0 & 0.0 & & $\mathrm{C}$ \\
\hline zesteno 1 (ev 1sind 1 ) & 88.9 & 0.0 & 11.1 & 60.0 & 10.0 & 30.0 & Non-act & $\mathrm{C}$ \\
\hline katedafizo (y1k1ld1) & 88.9 & 0.0 & 11.1 & 100.0 & 0.0 & 0.0 & Non-act & A \\
\hline veltiono (iyileşti) & 87.5 & 12.5 & 0.0 & 100.0 & 0.0 & 0.0 & Non-act & A \\
\hline \multicolumn{9}{|c|}{$\begin{array}{l}\text { Blue: high Turkish effect possible } \\
\text { Green: low Turkish effect possible } \\
\text { Gray: unknown effect }\end{array}$} \\
\hline
\end{tabular}

Table 1: Class A anticausatives in Istanbul Greek

The table above is structured as follows: verbs are given on the left, percentages of markedness for Istanbul Greek (IG) and Standard Greek (SG) are given in the middle, and the markedness of the Turkish counterparts (of the Greek verbs) together with corresponding Standard Greek anticausative classes are given on the right. The color codes on the lower side of the table show the degrees of possible Turkish effect in terms of language contact (between Istanbul Greek and Turkish). Note that I also marked the non-active suffixes in the Turkish translations of the Greek verbs with red (see the leftmost column).

My classification of verbs belonging to Class A in Istanbul Greek (also for the other classes, also for Standard Greek) is statistical. The classification permits verbs that are at least 85\% marked into Class A, both for Istanbul Greek (IG) and Standard Greek (SG). This is done in order to ignore any outliers in the data. 
Let us look at Table 1. Most of the Class A verbs in Istanbul Greek are also Class A verbs in Standard Greek. However, zesteno 1 (heat/warm up) constitutes an interesting example. The reason why I use the subscript 1 for this verb is the following: both in IG and SG, the verb zesteno belongs to two different classes in two different contexts. Class A zesteno 1 in IG is used in the following context:
a. To spiti
zestathike/*zestane.
the house.NOM warmed.NACT/warmed.ACT
"The house warmed up."

On the other hand, zesteno 2 is Class $\mathrm{C}$ in Istanbul Greek:

b. O kairos zestathike/zestane.

the weather.NOM warmed.NACT/warmed.ACT

"The weather warmed up."

Interestingly, Standard Greek also has a dichotomy between zesteno 1 and zesteno 2 in terms of classes. In SG, zesteno 1 is Class C (see Table 1), and zesteno 2 is class B (see Table 3). I claim that the difference can be explained by the concepts of internal and external causation (Alexiadou 2014). According to Alexiadou (2014:880), "externally caused change-of-state events imply the existence of an external causer with immediate control over the eventuality; on the other hand, internally caused change-of-state events involve properties inherent to the entities undergoing the events that are responsible for bringing about the eventuality." Then, this dichotomy makes sense as zesteno ${ }_{1}$ in (7a) implies external causation, while zesteno 2 in (7b) implies internal causation. As such, in IG, while zesteno ${ }_{1}$ tends to be non-actively marked, zesteno 2 is relatively unmarked in comparison with zesteno. Similarly, in Standard Greek (SG), zesteno $_{1}$ is optionally marked, while zesteno 2 is exclusively unmarked. Both in IG and SG, markedness increases when the verb implies external causation, and markedness decreases as the verb implies internal causation, which makes sense considering Haspelmath's (1993) crosslinguistic observation: "Events that are more likely to occur spontaneously will be associated with a conceptual stereotype (or prototype) of a spontaneous event, and this will be expressed in a structurally unmarked way."

But what about the difference between IG and SG in terms of the markedness of $z_{\text {zesteno }}$ ? In Istanbul Greek, the markedness of zesteno ${ }_{1}$ is nearly $30 \%$ higher compared to Standard Greek. I claim that this is due to the markedness of $\iota s i n m a k$ (warm up) in Turkish. Specifically, in Turkish, the verb isınmak carries the non-active reflexive marker -(I)n (Göksel and Kerslake 2005). As all Istanbul Greeks are Greek-Turkish bilinguals, interference, as proposed by Thomason (2003), results in the increased marking of zestenol based on the Turkish marked verb isinmak. Similar accounts of interference (or convergence) are found in the literature where, for example, Dutch-English bilinguals use uninflected forms of verbs rather than forms inflected for person based on the English pattern (Clyne 2003), or the SVO choice of Kadiwéu speakers among six possible native word orders when translating sentences from Portuguese, where this choice is based on the Portuguese pattern (Thomason 2003).

An even more relevant example comes from Lithuanian Romani, where originally monovalent verbs can optionally occur with a detransitivizing marker (reflexive in this case), copying the structure of Russian: 
(8)

a. Lithuanian Romani (Tenser 2005)
tume san
2PL laugh.2PL
"You laugh."
b. Lithuanian Romani (Tenser 2005)
tume san
2PL $\quad$ laugh.2PL

"You laugh."

c. Russian (Tenser 2005)

vy smejote $\quad \mathrm{sj}$

2PL laugh.2PL REFL

"You laugh."

According to Grossman and Witzlack-Makarevich (2019), this example from Lithuanian Romani constitutes an example of valency-copying, where a valency frame has been copied from one part of a multilingual repertoire into another (in this case from Russian to Lithuanian Romani). Another similar example is found in Hup where the passive verb is marked based on a valency frame copied from Tukano (Epps 2007). In my opinion, valency-copying can be regarded as a special case of interference (or convergence), and we can interpret the GreekTurkish bilingualism example along the theoretical line sketched here.

Going back to Istanbul Greek Class A verbs, we should also touch upon the case of the verb kovo (pluck/detach). Although kovo is a Class A verb in Istanbul Greek, it shows up as a Class $\mathrm{C}$ verb in Standard Greek. However, it barely misses the chance of being classified in Class A in Standard Greek (80\% markedness). Hence, I may say that the amount of outliers in the data for SG kovo may be higher than expected, resulting in the unknown effect for kovo.

7. Class B anticausatives in Istanbul Greek. Table 2 shows Class B verbs in Istanbul Greek.

\begin{tabular}{|c|c|c|c|c|c|c|c|c|}
\hline Verb & $\begin{array}{l}\text { Non- } \\
\text { active } \\
(\%)\end{array}$ & $\begin{array}{c}\text { Active } \\
(\%)\end{array}$ & $\begin{array}{l}\text { Either } \\
\text { one } \\
(\%)\end{array}$ & $\begin{array}{l}\text { Non- } \\
\text { active } \\
(\%)\end{array}$ & $\begin{array}{c}\text { Active } \\
(\%)\end{array}$ & $\begin{array}{l}\text { Either } \\
\text { one } \\
\text { (\%) }\end{array}$ & Marking & Class \\
\hline Act $\% \geq 85$ & \multicolumn{3}{|c|}{ Istanbul Greek } & \multicolumn{3}{|c|}{ Standard Greek } & Turkish & St. Gr. \\
\hline fardeno (genişledi) & 0.0 & 100.0 & 0.0 & 0.0 & 100.0 & 0.0 & 0 & $\mathrm{~B}$ \\
\hline klino (kapandı) & 11.1 & 88.9 & 0.0 & 0.0 & 100.0 & 0.0 & Non-act & B \\
\hline spao (k1r1ld1) & 11.1 & 88.9 & 0.0 & 0.0 & 100.0 & 0.0 & Non-act & B \\
\hline mavrizo (karard1) & 11.1 & 88.9 & 0.0 & 10.0 & 90.0 & 0.0 & 0 & B \\
\hline rodizo $(\mathrm{k} 1 \mathrm{zard} 1)$ & 11.1 & 88.9 & 0.0 & 0.0 & 100.0 & 0.0 & 0 & $\mathrm{~B}$ \\
\hline \multicolumn{9}{|c|}{$\begin{array}{l}\text { Blue: high Turkish effect possible } \\
\text { Green: low Turkish effect possible } \\
\text { Gray: unknown effect }\end{array}$} \\
\hline
\end{tabular}

Table 2: Class B anticausatives in Istanbul Greek

My classification for Class B verbs again applies the same rules: a verb is accepted into Class B if the active usage percentage is at least $85 \%$ (both for IG and SG). Then, all Istanbul Greek Class B verbs are also Class B verbs in Standard Greek, which shows that no verbs from other SG classes entered Class B in Istanbul Greek due to Turkish contact. Also, in terms of the correlation between IG and Turkish markedness, three out of five IG Class B verbs considered 
here are already unmarked in Turkish. Out of the IG verbs whose Turkish counterparts are marked, spao (break) is an exception, as it cannot combine with the non-active morpheme in Greek due to morphophonological reasons (Alexiadou et al. 2015). Lastly, the verb klino (close) is widely used in Greek, and the active form is very established. Hence, we would not expect to find Turkish effect on its usage, although its Turkish counterpart kapanmak (close) is marked. Still, one can notice that there is a slight correlation between the markedness of IG verbs and the markedness of their Turkish counterparts. In Class A (see Table 1), the Turkish counterparts of IG verbs are $70 \%$ marked, while in Class B, Turkish counterparts are $25 \%$ marked (excluding spao). This phenomenon is probably due to the crosslinguistic tendencies of markedness for certain verbs, but may still have been reinforced by the marking of the Turkish counterparts of IG Class A and Class B verbs.

8. Class $\mathbf{C}$ anticausatives in Istanbul Greek. Table 3 shows $\mathrm{Class} C$ verbs in Istanbul Greek.

\begin{tabular}{|c|c|c|c|c|c|c|c|c|}
\hline Verb & $\begin{array}{l}\text { Non- } \\
\text { active } \\
(\%)\end{array}$ & $\begin{array}{c}\text { Active } \\
(\%)\end{array}$ & $\begin{array}{l}\text { Either } \\
\text { one } \\
(\%)\end{array}$ & $\begin{array}{l}\text { Non- } \\
\text { active } \\
(\%)\end{array}$ & $\begin{array}{c}\text { Active } \\
(\%)\end{array}$ & $\begin{array}{l}\text { Either } \\
\text { one } \\
(\%)\end{array}$ & Marking & Class \\
\hline Non-act, Act $\%<85$ & \multicolumn{3}{|c|}{ Istanbul Greek } & \multicolumn{3}{|c|}{ Standard Greek } & Turkish & St. Gr. \\
\hline tsalakono (buruştu) & 75.0 & 12.5 & 12.5 & 60.0 & 30.0 & 10.0 & Non-act & $\mathrm{C}$ \\
\hline lerono (kirlendi) & 66.7 & 0.0 & 33.3 & 80.0 & 20.0 & 0.0 & Non-act & $\mathrm{C}$ \\
\hline vithizo (batt1) & 55.6 & 22.2 & 22.2 & 100.0 & 0.0 & 0.0 & 0 & A \\
\hline zesteno 2 (hava 1 sind 1 ) & 55.6 & 22.2 & 22.2 & 0.0 & 100.0 & 0.0 & Non-act & B \\
\hline gremizo (çöktü) & 44.4 & 44.4 & 11.1 & 90.0 & 10.0 & 0.0 & 0 & A \\
\hline katharizo (temizlendi) & 44.4 & 33.3 & 22.2 & 10.0 & 80.0 & 10.0 & Non-act & $\mathrm{C}$ \\
\hline svino (söndiu) & 22.2 & 66.7 & 11.1 & 0.0 & 100.0 & 0.0 & Non-act & B \\
\hline anigo (kap1 açıld1) & 22.2 & 77.8 & 0.0 & 0.0 & 100.0 & 0.0 & Non-act & B \\
\hline yirizo (döndü) & 22.2 & 77.8 & 0.0 & 0.0 & 100.0 & 0.0 & Non-act & B \\
\hline asprizo (beyazladi) & 11.1 & 77.8 & 11.1 & 0.0 & 100.0 & 0.0 & & B \\
\hline zarono (cildi kırıştı) & 11.1 & 66.7 & 22.2 & 0.0 & 100.0 & 0.0 & Non-act & $\mathrm{B}$ \\
\hline \multicolumn{9}{|c|}{$\begin{array}{l}\text { Blue: high Turkish effect possible } \\
\text { Green: low Turkish effect possible } \\
\text { Gray: unknown effect }\end{array}$} \\
\hline
\end{tabular}

Table 3: Class $\mathrm{C}$ anticausatives in Istanbul Greek

The classification of IG and SG Class $\mathrm{C}$ verbs is based on the following rule: a verb is placed in Class $\mathrm{C}$ if it does not enter Class A or Class B. Hence, the verbs in Class $\mathrm{C}$ show a greater degree of optionality in terms of marking compared to the other classes, as suggested by Alexiadou et al. (2015).

In Table 3, we can notice that there are mismatches between IG and SG anticausative classes for the vast majority of IG Class C anticausatives and their SG counterparts. Consider the verb vithizo (sink). This verb is exclusively marked in Standard Greek. On the other hand, it shows great variation in Istanbul Greek, and it is strictly marked only in 55.6\% of the cases. Moreover, the Turkish counterpart of vithizo is batmak (sink) in Turkish, which is unmarked. Hence, I claim that in IG, there are cases where vithizo is unmarked based on a valency frame copied from Turkish unmarked batmak (Grossman and Witzlack-Makarevich 2019). Another such example is the case of the IG verb gremizo (collapse). Although gremizo is Class A in Standard Greek, it is Class C in Istanbul Greek, and shows great variation. Moreover, the 
variation is towards being unmarked compared to SG (see Table 3). I claim that this is also caused by the valency frame of its unmarked Turkish counterpart, which is çökmek ${ }^{4}$ (collapse). Of course, I should remind the reader that I consider valency-copying to be a special case of interference, or convergence in this case (Grossman and Witzlack-Makarevich 2019; Thomason 2003; Clyne 2003).

There are also cases where the tendencies of markedness turn the other way round. Consider the verb katharizo (clean/get clean). Although it is a Class C verb in SG, it is mostly unmarked (80\%, see Table 3). On the other hand, in IG, data shows that katharizo is mostly marked (44.4\%). I claim that this is due to the valency frame of its marked Turkish counterpart temizlenmek (get clean). A similar example is the case of zesteno (warm up), which is exclusively unmarked in Standard Greek, but 55.6\% marked in Istanbul Greek. Again, I claim that IG zesteno 2 tends to be marked because of the copied valency frame from its marked Turkish counterpart isinmak (warm up). Note that zesteno 2 (warm up, in the case of weather) differs from zesteno $_{1}$ (warm up, as in "the house warmed up") in terms of class both in IG and SG (see section 4).

Another interesting case is that of the verb tsalakono (crumple). Although this verb is Class $\mathrm{C}$ both in IG and SG, its markedness is higher in IG compared to SG (75\% non-active marking in IG vs. $60 \%$ in SG, see Table 3). The Turkish counterpart of tsalakono is the verb buruşmak (crumple), which carries the suffix -(I)ş. According to Nişanyan (2009), the suffix -(I)ş also functions as a reflexive marker when attached to some verbs. For buruşmak, apart from being a non-active marker, I claim that the -(I)ş suffix can also be considered as a reflexive marker. To elaborate, the reader can consider the relationship between burmak (twist) vs. buruşmak (crumple), where intransitive buruşmak can also be interpreted as "becoming twisted". Hence, the difference in markedness between IG and SG can be due to the non-active nature of the verb buruşmak (crumple), where the marking of tsalakono (crumple) converges to that of its Turkish counterpart due to valency-copying.

A similar example is the case of zarono (wrinkle), where its Turkish counterpart kırışmak (wrinkle) also carries the non-active suffix $-(I)$ ş. In Standard Greek, the verb zarono is exclusively unmarked, while in Istanbul Greek, it is exclusively unmarked only in $66.7 \%$ of the cases. The shift from being unmarked to markedness, I claim, is due to the markedness of the Turkish counterpart of zarono. Now, consider the verb kırışmak (wrinkle). According to Nişanyan (2009), kırışmak etymologically descends from kıvrışmak (be curled). Note that the form kıvrışmak is not used in Standard Modern Turkish. When we consider the difference between transitive kıvırmak (curl up) vs. kıvrışmak (be curled), we can see that the suffix -(I)ş again functions as a reflexive marker. Moreover, even if we assume that the bilinguals do not have access to the etymological information, we can still argue that they may have parsed the $-(I)$ ş morpheme on kırışmak as simple non-active morphology by analogy to the reciprocal -(I)ş. Hence, we can say that the relative markedness of zarono (wrinkle) in Istanbul Greek is due to the valency frame copied from its marked Turkish counterpart kırışmak (wrinkle).

There are also other IG Class $\mathrm{C}$ verbs like zarono (wrinkle) which are Class B verbs in Standard Greek: anigo (open), svino (burn out), yirizo (turn), asprizo (whiten). The relative markedness of anigo (open) in IG (compared to SG) is relatively easy to explain, as its Turkish

\footnotetext{
${ }^{4}$ Collapse may also be translated into Turkish as ylklmak, which carries non-active morphology. In this case, my analysis for IG gremizo (collapse) would not hold. For how to translate collapse into Turkish, further investigation is needed in terms of how Istanbul Greeks translate gremizo into Turkish in the context of the experimental sentences that I used during data collection.
} 
anticausative counterpart açılmak (be opened) carries non-active morphology (see Table 3 for the difference in markedness for IG anigo and SG anigo). For svino (burn out) and yirizo (turn), I want to touch upon their markedness in Turkish. The Turkish counterparts of svino and yirizo are sönmek (burn out) and dönmek (turn), which end with the non-active morpheme -(I)n. Although these verbs are bare roots in Modern Turkish, they etymologically descend from the verb root combined with the non-active morpheme -(I)n (Nişanyan 2009). Note that $-(I) n$ is the reflexive marker in Turkish (Göksel and Kerslake 2005). Some similar verbs whose roots end in -(I)n are yanmak (be burned), and konmak (be put). Hence, I claim that these are marked verbs in Turkish, although they are bare roots. Then, we can explain the relative markedness of svino and yirizo through the copied valency frames from sönmek and dönmek respectively.

Lastly, I want to touch upon the case of asprizo (whiten), which is a Class C verb in IG, and a Class B verb in SG. Table 3 shows that asprizo is exclusively unmarked in SG, while it is unmarked in $77.8 \%$ of the cases in IG. On the other hand, the Turkish counterpart of asprizo, which is beyazlamak (whiten), is also unmarked. Then, we cannot explain the relative markedness of asprizo in IG by the markedness of its Turkish counterpart, as things stand. However, I have noticed during my interviews with Istanbul Greek speakers that some translate asprizo into Turkish as beyazlanmak (be whitened) with the reflexive morpheme -(I)n. Then, for the marked cases of asprizo in IG, we may say that they are marked based on the valency frame of the form beyazlanmak.

9. Conclusion. The results of this study show that there is little variation between Istanbul Greek Class A and Class B verbs and their SG counterparts in terms of markedness. On the other hand, the markedness of IG anticausatives is correlated with the markedness of their Turkish counterparts, contrary to SG, especially for IG Class C verbs. As all Istanbul Greeks (Rums) are Greek-Turkish bilinguals, interference (Thomason 2003) results in some Istanbul Greek anticausatives to be marked based on the pattern of their Turkish counterparts. Specifically, we have a case of convergence (Clyne 2003), considering this correlation. This convergence can be explained by the concept of valency-copying (Grossman and Witzlack-Makarevich 2019), in regard of the language contact between Istanbul Greek and Turkish. 


\section{References}

Alexiadou, Artemis \& Elena Anagnostopoulou. 2004. Voice morphology in the causativeinchoative alternation: Evidence for a non-unified structural analysis of unaccusatives. In Artemis Alexiadou, Elena Anagnostopoulou \& Martin Everaert (eds.), The unaccusativity puzzle. 114-136. Oxford: Oxford University Press. https://doi.org/10.1093/acprof:oso/9780199257652.003.0005

Alexiadou, Artemis. 2014. The problem with internally caused change-of-state verbs. Linguistics 52(4). 879-909. https://doi.org/10.1515/ling-2014-0011

Alexiadou, Artemis, Elena Anagnostopoulou \& Florian Schäfer. 2015. External arguments in transitivity alternations: A layering approach. Oxford: Oxford University Press. https://doi.org/10.1093/acprof:oso/9780199571949.001.0001

Clyne, Michael. 2003. Dynamics of language contact. Cambridge: CUP. https://doi.org/10.1017/CBO9780511606526

Epps, Patience. 2007. Grammatical borrowing in Hup. In Yaron Matras \& Jeanette Sakel (eds.), Grammatical borrowing in cross-linguistic perspective. 551-566. Berlin: Mouton de Gruyter. https://doi.org/10.1515/9783110199192.551

Göksel, Asl1. 1993. Levels of Representation and Argument Structure in Turkish. London: University of London PhD Dissertation.

Göksel, Aslı \& Celia Kerslake. 2005. Turkish: a comprehensive grammar. London, New York: Routledge. https://doi.org/10.4324/9780203340769

Grossman, Eitan \& Alena Witzlack-Makarevich. 2019. Valency and transitivity in contact: An overview. Journal of Language Contact 12(1). 1-26. https://doi.org/10.1163/19552629-01201001

Gündoğdu, Songül. 2016. -(I)1 / -(I)n morphology in Turkish: Implications for u-syncretism. Proceedings of PICGL4. 85-103.

Haspelmath, Martin. 1993. More on the typology of inchoative/causative verb alternations. In Bernard Comrie \& Maria Polinsky (eds.), Causatives and transitivity. 87-120. Amsterdam: John Benjamins. https://doi.org/10.1075/slcs.23.05has

Kaya, Neşe. 2011. Ambivalent belongings: A discourse analysis of second generation Cretan immigrants in Cunda. İstanbul: Boğaziçi University MA thesis.

Komondouros, Markos \& Lisa McEntee-Atalianis. 2007. Language attitudes, shift and the ethnolinguistic vitality of the Greek Orthodox community in Istanbul. Journal of Multilingual and Multicultural Development 28(5). 365-384. https://doi.org/10.2167/jmmd483.1

Nişanyan, Sevan. 2009. Sözlerin Soyağacı: Çă̆daş Türkçenin Etimolojik Sözlüğü. İstanbul: Everest.

Rompopoulou, Maria. 2018. Bilingualism in younger generation of Greek Orthodox community in Istanbul: The language use of Greek and Turkish languages in Greek minority educational institutions. In Peter Trifonas \& Themistoklis Aravossitas (eds.), Handbook of research and practice in heritage language education. 539-560. Cham: Springer.

https://doi.org/10.1007/978-3-319-38893-9_30-1 
Schaaik, Gerjan van. 2020. The Oxford Turkish grammar. Oxford: Oxford University Press. https://doi.org/10.1093/oso/9780198851509.001.0001

Tenser, Anton. 2005. Lithuanian Romani. Munich: Lincom.

Thomason, Sarah G. 2003. Contact as a source of language change. In Brian D. Joseph \& Richard D. Janda (eds.), The handbook of historical linguistics. 687-712. Oxford:

Blackwell. https://doi.org/10.1002/9781405166201.ch23

Underhill, Robert. 1985. Turkish grammar. Cambridge, Massachusetts, and London, England: The MIT Press. 